\title{
PRE-NATAL GROWTH OF MONGOLOID DEFECTIVES
}

\author{
BY \\ ALWYN SMITH and THOMAS MCKEOWN \\ From the Department of Social Medicine, University of Birmingham
}

(RECEIVED FOR PUBLICATION OCTOBER 28, 1954)

The literature contains several references to the maturity of mongols at birth. Southwick (1939) noted that the mean birth weight $(7.08 \mathrm{lb}$.) of 108 mongols was only slightly below normal, but in most reports it is stated that affected children are frequently 'premature', although criteria of maturity are not always specified. Nevertheless, there is evidence that the birth weight of mongols is low (Schröder, 1938; Benda, 1939; Øster, 1953), and that the period of their gestation is shorter than normal (Beidleman, 1945; Øster, 1953). The reported data do not, however, permit one to decide whether the low weight at birth is due wholly to the short duration of gestation, or is attributable in part to a reduced rate of pre-natal growth.

To come to a decision on this matter we require to know the mean birth weight according to duration of gestation, both for a group of mongols and for a population of normal births. Information of this kind was obtained in an enquiry in which an attempt was made to trace all mongols born in Birmingham during the 11 years 1942-52. (A fuller description of this material is provided by Record and Smith, 1955.) Two hundred and fifty-two mongols were identified, of whom 120 were born in hospitals. For 103 of the hospital cases data in hospital notes included birth weight and duration of gestation (from the first day of the last menstrual period preceding pregnancy to birth). For 66 of the 103 individuals the weight of the placenta was also recorded.

Although the same observations were not available in respect of the total population of hospital births in the period 1942-52, they were obtained in an earlier enquiry (McKeown and Record, 1953) for 4,931 of the 7,341 single live births delivered in the Birmingham Maternity Hospital during the four years 1946 and 1948 to 1950 .

Table 1 compares the weight distribution of the 103 mongols with that of the 4,931 controls; mean weights are $6 \cdot 38$ and $7 \cdot 10 \mathrm{lb}$. respectively. For all births $(9,699)$ delivered in Birmingham hospitals during 1947, the mean weight was $7 \cdot 15 \mathrm{lb}$. (McKeown and Gibson, 1951), so that although the
4,931 controls are selected from births in one hospital during four years, it seems probable that in respect of weight distribution they are reasonably representative of all hospital births in the city during the 11-year period from which the mongols were drawn. The evidence in Table 1 is consistent with

TABLE 1

COMPARISON OF WEIGHT DISTRIBUTION OF MONGOLS AND CONTROLS

\begin{tabular}{|c|c|c|c|c|}
\hline \multirow{2}{*}{$\begin{array}{l}\text { Weight } \\
\text { (lb.) }\end{array}$} & . & \multicolumn{2}{|c|}{ Mongols } & \multirow{2}{*}{$\begin{array}{c}\text { 4,931 Hospital } \\
\text { Single Births } \\
(\%)\end{array}$} \\
\hline & & No. & $\%$ & \\
\hline $\begin{array}{ll}\text { Under } & 4 \\
4 & \ldots \\
4 \frac{1}{2}- & \ldots \\
5- & \ldots \\
5 \frac{1}{2}- & \ldots \\
6- & \ldots \\
6 \frac{1}{2}- & \ldots \\
7- & \ldots \\
7 \frac{1}{2}- & \ldots \\
8- & \ldots \\
8 \frac{1}{2}- & \ldots \\
9 \text { and over }\end{array}$ & $\begin{array}{l}\ldots \\
\cdots \\
\ldots \\
\ldots \\
\ldots \\
\ldots \\
\ldots \\
\cdots \\
\cdots \\
\cdots\end{array}$ & $\begin{array}{r}-3 \\
8 \\
8 \\
20 \\
15 \\
16 \\
16 \\
7 \\
7 \\
3\end{array}$ & $\begin{array}{r}2 \cdot 9 \\
7 \cdot 8 \\
7 \cdot 8 \\
19 \cdot 4 \\
14 \cdot 6 \\
15 \cdot 5 \\
15 \cdot 5 \\
6 \cdot 8 \\
6 \cdot 8 \\
2 \cdot 9\end{array}$ & $\begin{array}{r}2 \cdot 6 \\
1 \cdot 3 \\
2 \cdot 5 \\
4 \cdot 1 \\
6 \cdot 3 \\
11 \cdot 3 \\
14 \cdot 0 \\
17 \cdot 3 \\
15 \cdot 1 \\
11 \cdot 3 \\
7 \cdot 4 \\
6 \cdot 8\end{array}$ \\
\hline Total & . & 103 & $100 \cdot 0$ & $100 \cdot 0$ \\
\hline
\end{tabular}

TABLE 2

DISTRIBUTION OF MONGOLS AND CONTROLS ACCORDING TO LENGTH OF GESTATION

\begin{tabular}{|c|c|c|c|c|}
\hline \multirow{2}{*}{$\begin{array}{l}\text { Gestation } \\
\text { (weeks) }\end{array}$} & & \multicolumn{2}{|c|}{ Mongols } & \multirow{2}{*}{$\begin{array}{c}\text { 4,931 Hospital } \\
\text { Single Births } \\
(\%)\end{array}$} \\
\hline & & No. & $\%$ & \\
\hline Under 31 & $\ldots$ & - & - & 0.5 \\
\hline $31-\quad \ldots$ & $\therefore$ & 1 & $1 \cdot 0$ & 0.5 \\
\hline $32-$ & $\cdots$ & 3 & 2.9 & 0.7 \\
\hline $33-$ & $\therefore$ & 4 & $3 \cdot 9$ & 0.7 \\
\hline 34 & .. & - & - & $1 \cdot 1$ \\
\hline $35-$ & $\cdots$ & 5 & $4 \cdot 9$ & $2 \cdot 2$ \\
\hline $36-$ & .. & 10 & $9 \cdot 7$ & $4 \cdot 4$ \\
\hline 37- & $\therefore$ & 15 & $14 \cdot 5$ & $7 \cdot 5$ \\
\hline & $\ldots$ & 21 & $20 \cdot 4$ & $12 \cdot 8$ \\
\hline 39- & .. & 20 & $19 \cdot 4$ & 17.9 \\
\hline 40- & .. & 11 & $10 \cdot 7$ & $22 \cdot 1$ \\
\hline 41- & .. & 8 & $7 \cdot 8$ & $17 \cdot 0$ \\
\hline 42- & . & 2 & $1 \cdot 9$ & $8 \cdot 1$ \\
\hline 43- & .. & 2 & 1.9 & $3 \cdot 0$ \\
\hline 44 & $\cdots$ & 1 & $1 \cdot 0$ & $1 \cdot 0$ \\
\hline 45 and over & $\cdots$ & - & - & 0.6 \\
\hline Total & . & 103 & 100 & 100 \\
\hline
\end{tabular}


other reports that the birth weight of mongols is low.

The low weight is accounted for to some extent by early onset of labour. Table 2 gives the distribution of mongols and controls according to duration of gestation; the means are 268.9 and 278.4 days respectively ( $279 \cdot 7$ for 8,292 births in all Birmingham hospitals during 1947).

Their short period of gestation does not, however, entirely explain the low birth weight of mongols, which must be attributed in part to a reduced rate of pre-natal growth. In Table 3 mean foetal weight

TABLE 3

MEAN FOETAL AND PLACENTAL WEIGHT ACCORDING TO DURATION OF GESTATION

\begin{tabular}{|c|c|c|c|c|c|c|}
\hline & & \multicolumn{5}{|c|}{ Duration of Gestation (weeks) } \\
\hline & & 30 & $36-$ & $38-$ & $40-45$ & Total \\
\hline $\begin{array}{l}\text { Foetal } \\
\text { weight (lb.) }\end{array}$ & $\begin{array}{l}\text { Mongols } \\
\text { Controls }\end{array}$ & $\begin{array}{l}5 \cdot 52 \\
(13) \\
4 \cdot 67 \\
(266)\end{array}$ & $\begin{array}{l}6 \cdot 25 \\
(25) \\
6 \cdot 20 \\
(585)\end{array}$ & $\begin{array}{c}6 \cdot 46 \\
(41) \\
7 \cdot 06 \\
(1,513)\end{array}$ & $\begin{array}{c}6 \cdot 84 \\
(24) \\
7 \cdot 60 \\
(2,547)\end{array}$ & $\begin{array}{c}6 \cdot 38 \\
(103) \\
7 \cdot 11 \\
(4,911)\end{array}$ \\
\hline $\begin{array}{l}\text { Placental } \\
\text { weight (lb.) }\end{array}$ & $\begin{array}{l}\text { Mongols } \\
\text { Controls }\end{array}$ & $\begin{array}{l}1 \cdot 07 \\
(7) \\
1 \cdot 11 \\
(266)\end{array}$ & $\begin{array}{l}1 \cdot 30 \\
(14) \\
1 \cdot 31 \\
(585)\end{array}$ & $\begin{array}{c}1 \cdot 36 \\
(28) \\
1 \cdot 38 \\
(1,513)\end{array}$ & $\begin{array}{c}1 \cdot 37 \\
(17) \\
1 \cdot 46 \\
(2,547)\end{array}$ & $\begin{array}{c}1 \cdot 32 \\
(66) \\
1.40 \\
(4.911)\end{array}$ \\
\hline
\end{tabular}

according to gestation is given for 103 mongols, and for 4,911 of the 4,931 controls (20 control births whose duration of gestation was less than 30 weeks or more than 45 weeks are excluded). The numbers of mongols are of course very small for this purpose, but the results appear to justify the conclusion that at least from about the thirty-eighth week of gestation mongols are lighter in weight than unaffected births delivered at corresponding stages of gestation.

Table 3 also gives mean placental weight according to duration of gestation for 66 cases for which the information was available and for controls. The

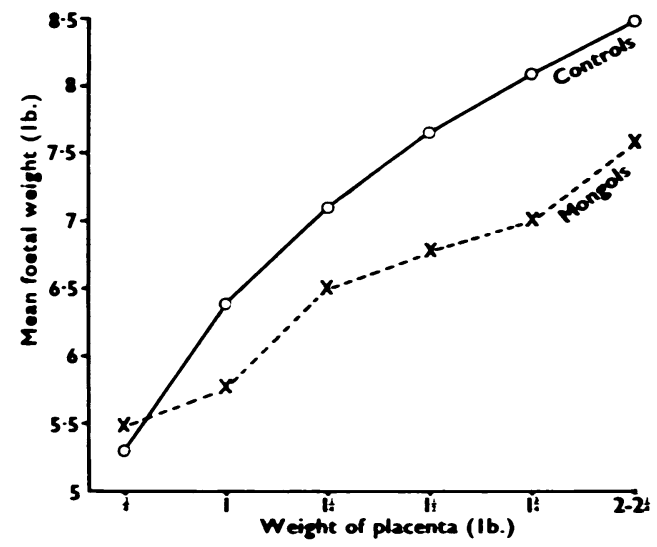

FiG. 1-Foetal weight acoording to placental weight. slight differences exhibited in Table 3 do not suggest that the placentae of mongols are lighter in weight than those of normal births. There is, however, a fairly sharp difference between foetal weights at

TABLE 4

MEAN FOETAL WEIGHT ACCORDING TO PLACENTAL WEIGHI

\begin{tabular}{|c|c|c|c|c|c|c|}
\hline $\begin{array}{l}\text { Weight of } \\
\text { placenta (lb.) }\end{array}$ & $1-$ & $1-$ & $1 t-$ & $1 \underline{z}-$ & $1\}$ & $2-2 t$ \\
\hline Mongols . . & $\begin{array}{c}5 \cdot 49 \\
(5)\end{array}$ & $\begin{array}{l}5 \cdot 77 \\
(20)\end{array}$ & $\begin{array}{l}6 \cdot 50 \\
(22)\end{array}$ & $\begin{array}{l}6 \cdot 77 \\
(12)\end{array}$ & $\begin{array}{c}7 \cdot 00 \\
(3)\end{array}$ & $\begin{array}{c}7 \cdot 58 \\
(3)\end{array}$ \\
\hline Controls & $\begin{array}{r}5 \cdot 29 \\
(231)\end{array}$ & $\begin{array}{l}6 \cdot 38 \\
(858)\end{array}$ & $\begin{array}{c}7 \cdot 09 \\
(1,476)\end{array}$ & $\begin{array}{l}7 \cdot 65 \\
(954)\end{array}$ & $\begin{array}{l}8 \cdot 08 \\
(447)\end{array}$ & $\begin{array}{l}8 \cdot 48 \\
(120)\end{array}$ \\
\hline
\end{tabular}

corresponding placental weights (Table 4 and Fig. 1). At all placental weights greater than $\frac{3}{4} \mathrm{lb}$. the weight of mongols is substantially lower than that of controls.

These results are consistent with other reports that the birth weight of mongols is low, and that the period of their gestation is shorter than normal. The low weight is not, however, entirely due to the early onset of labour, and, as in multiple pregnancy, must be attributed in part to a low rate of pre-natal growth. But in multiple pregnancy retardation of pre-natal growth is associated with a low placental weight (McKeown and Record, 1953), whereas the placentae of mongols appear to be of approximately normal weight (Table 3). This is not, of course, to say that the placentae are normal in all respects; but in view of the possible significance of the uterine environment in the aetiology of mongolism, it is of interest that the uterus appears to be capable of supporting a placenta of normal weight. The retardation of pre-natal growth of mongols may be due to a lowered growth capacity of the foetus, rather than to the inability of the uterine environment to support its growth. The marked inhibition of post-natal growth (Benda, 1939; бster, 1953) is consistent with this view.

\section{Summary}

Data are recorded on 103 mongols delivered in Birmingham hospitals during the 11 years 1942-52, and on 4,931 single live births delivered in the Birmingham Maternity Hospital during the four years 1946 and 1948-50. In the two groups respectively mean birth weights were 6.38 and $7 \cdot 10 \mathrm{lb}$., and mean durations of gestation 268.9 and 278.4 days. The low birth weight of mongols is not entirely explained by the early onset of labour, but must be attributed in part to a low rate of pre-natal growth. The retardation of growth is not, however, 
associated with a low placental weight and may be due to a lowered growth capacity of the foetus, rather than to the inability of the pre-natal environment to support its growth.

For permission to examine records we are indebted to the staffs of Birmingham hospitals.
REFERENCES

Beidleman, B. (1945). Amer. J. ment. Defic., 50, 35.

Benda, C. E. (1939). Arch. Neurol. Psychiat. Chicago, 41, 83

McKeown, T. and Gibson, J. R. (1951). Brit. J. sac. Med., 5, 98

MeKd Record, R. G. (1953). J. Endocrin., 9, 418.

Oster, J. (1953). Mongolism: a clinicogenealogical investigation comprising 526 mongols living on Secland and neighbouring islands in Denmark Danish Science Press, Copenhagen.

Record, R. G. and Smith, A. (1955). Brit. J. prev. soc. Med., 9, 10.

Schröder. H. (1938). Z, ges. Neurol. Psvchiat., 163, 390.

Southwick, W. E. (1939). Amer. J. Dis. Child., 57, 68. 